\title{
The effect of cholestyramine on intestinal absorption
}

\author{
R. J. WEST AND J. K. LLOYD \\ From the Department of Child Health, Institute of Child Health, Guildford Street, London
}

SUMMARY Cholestyramine in a mean dosage of $0.6 \mathrm{~g} / \mathrm{kg} /$ day has been given to 18 children with familial hypercholesterolaemia for between one and two and a half years.

With prolonged treatment folate deficiency occurred, as evidenced by a fall in the mean serum folate concentration from $7.7 \mathrm{ng} / \mathrm{ml}$ before treatment to $4.4 \mathrm{ng} / \mathrm{ml}$ for patients on treatment for over one year; a corresponding lowering of red cell folate was also seen. Oral folic acid $5 \mathrm{mg}$ daily overcame this depletion, and should be given to all patients on long-term anion exchange resins.

Prothrombin time has remained normal in all patients; there has been a significant decrease in the mean serum concentrations of vitamins $A$ and $E$ and of inorganic phosphorus over the first two years of treatment, although values remain within the normal range. The routine administration of fat-soluble vitamins appears unnecessary but it is prudent to measure prothrombin time and serum vitamins $A$ and $E$ at intervals.

In children who were having a normal intake of dietary fat five out of seven tested had faecal fat of over $5 \mathrm{~g}$ /day while on cholestyramine. No child has developed diarrhoea, and growth has been normal.

The concentrations of serum iron, vitamin $\mathbf{B}_{12}$, plasma calcium, and protein did not change significantly in any patient.

Cholestyramine is a non-absorbable anion exchange resin which binds bile acids in the intestine thus preventing their reabsorption in the ileum. It was introduced into therapeutics for the treatment of hypercholesterolaemia in 1959 (Bergen, Van Itallie, Tennent, and Sebrell, 1959) and shortly after it was shown to relieve the pruritas in some cases of obstructive jaundice (Datta and Sherlock, 1963). More recently cholestyramine has been used in the treatment of diarrhoea following intestinal resection (Hofmann and Poley, 1969) and for the hyperoxaluria of ileal disease (Smith, Fromm, and Hofmann, 1972).

With the increasing use of the resin for long-term management of hypercholesterolaemia, it is important to define its side effects. In large doses cholestyramine has been reported to cause steatorrhoea (Hashim, Bergen, and Van Itallie, 1961) and it has been suggested that malabsorption of fat-soluble vitamins and minerals might occur either as a result of direct binding to the resin or as a secondary manifestation of the steatorrhoea; it is therefore generally recommended that fat-soluble vitamins are given to patients requiring prolonged treatment, although reports of deficiencies in patients on longterm treatment are scanty and only calcium and vitamin $\mathrm{K}$ seem to have been studied systematically (Hashim and Van Itallie, 1965; Fallon and Woods, 1968).

As part of a study of the use of cholestyramine for the treatment of familial hypercholesterolaemia (familial type II hyperlipoproteinaemia) in children, we have carried out investigations to monitor the effect of long-term treatment on the absorption of fat, vitamins, and some minerals. The results of these studies and their therapeutic implications are reported in this paper.

\section{Patients and Methods}

Eighteen children aged 1 to 14 years, with the heterozygous form of familial hypercholesterolaemia, have been treated with Questran ${ }^{1}$ brand cholestyramine. In the majority there was a history of premature ischaemic heart disease in a near relative. None of the children had any evidence of heart disease, two had corneal arcus, and one had skin xanthomata and was also overweight. 
For 16 children cholestyramine was given twice daily, before breakfast and before the evening meal, in a dose of 0.2 to $1 \cdot 1$ (mean 0.6$) \mathrm{g} / \mathrm{kg} /$ day; two children took an equivalent dose three times daily. Eight children remained on their normal diet, and 10 were initially given a diet low in saturated fats (between 9 and $35 \mathrm{~g} /$ day) supplemented with corn oil and corn oil products; it was later possible, however, to increase the dietary saturated fat to amounts approaching the normal intake. No patient received vitamin or mineral supplements.

In eight patients in whom treatment was started in hospital faecal fat was determined before and during administration of cholestyramine; in one further child estimations were only made during therapy. In four of these patients faecal collections were made on at least two dosage increments. Faecal collections were not made until at least five days after the start of any given drug dosage; collection periods ranged from three to five days. Stools were pooled and faecal fat was extracted as described by van de Kamer, ten Bokkel Huinink, and Weyers (1949) and then estimated gravimetrically.

Of the 18 patients in the study, one was followed up elsewhere, but for the other 17 haemoglobin, prothrombin time, plasma calcium, phosphorus, protein and alkaline phosphatase, serum folate, iron, and vitamins $B_{12}, A$, and $E$ were estimated in the majority before starting cholestyramine treatment, and in all at approximately three-month intervals thereafter. Red blood cell folate was not determined at the beginning of the study but was later added to the investigations performed.
Vitamin $\mathrm{E}$ was estimated by the method based on that of Quaife and Harris (1944) and all the other investigations by standard methods in the routine laboratories of The Hospital for Sick Children. All patients have been followed for at least one year, and nine have been on cholestyramine for at least two years (range one to two and a half years). The height and weight of each child was recorded at each clinic visit.

\section{Results}

Control of serum cholesterol was judged satisfactory in all patients, suggesting that cholestyramine was being taken regularly in spite of its relative unpalatability (mainly due to its bulk), which caused some problems of administration. A few children complained of fullness after cholestyramine, but none had abdominal pain or constipation. The mean serum cholesterol concentration for the group during the follow-up period is shown in table I.

\section{FAECAL FAT}

Some increase in stool frequency occurred in most children (up to three stools/day) but no child had loose stools. Figure 1 shows faecal fat in nine patients related to the dose of cholestyramine. In the six children who remained on a normal diet fat excretion increased during cholestyramine treatment, but only four had definite steatorrhoea (greater than 5 $\mathrm{g}$ /day). In two patients on low-fat diets no increase in fat excretion occurred with cholestyramine. One further patient, whose fat excretion was $1.4 \mathrm{~g} /$ day on

\begin{tabular}{|c|c|c|c|c|c|}
\hline \multirow[t]{2}{*}{ Investigation } & \multicolumn{5}{|c|}{ Duration of Cholestyramine Treatment (Months) } \\
\hline & 0 & $\rightarrow 6$ & $\rightarrow 12$ & $\rightarrow 18$ & $\rightarrow 24$ \\
\hline $\begin{array}{l}\text { Serum cholesterol } \\
(\mathrm{mg} / 100 \mathrm{ml})\end{array}$ & $\begin{array}{l}372 \cdot \\
(17)\end{array} \pm 9$ & $\begin{array}{l}256^{2} \\
(17)\end{array}$ & $\begin{array}{l}255^{2} \\
(17)\end{array}$ & $\begin{array}{l}258^{2} \\
(17)\end{array}$ & $\begin{array}{l}247^{2} \\
(13)\end{array} \pm 11$ \\
\hline $\begin{array}{l}\text { Serum vitamin A } \\
\text { (IU } / \mathrm{ml} \text { ) }\end{array}$ & $\begin{array}{l}151 \\
(11)\end{array} \pm 15$ & $\begin{array}{l}125 \\
(15)\end{array}$ & $\begin{array}{l}134 \\
(14)\end{array}$ & $\begin{array}{l}156 \\
(15)\end{array} \pm 12$ & $\begin{array}{l}83^{2} \\
(8)\end{array} \pm 19$ \\
\hline $\begin{array}{l}\text { Serum vitamin } E \\
(\mathrm{mg} / 100 \mathrm{ml})\end{array}$ & $\begin{array}{l}1.4 \\
(9)\end{array}$ & $\begin{array}{l}1 \cdot 3 \\
(16)\end{array}$ & $\begin{array}{l}1 \cdot 2 \\
(17)\end{array}$ & $\begin{array}{l}1 \cdot 2 \\
(16)\end{array}$ & $\begin{array}{l}1 \cdot 1^{2} \\
(10)\end{array}$ \\
\hline $\begin{array}{l}\text { Serum vitamin } B_{12} \\
(\mathrm{pg} / \mathrm{ml})\end{array}$ & $\begin{array}{r}851 \\
(7)\end{array}$ & $\begin{array}{l}630 \pm 57 \\
(15)\end{array}$ & $\begin{array}{l}780 \\
(17)\end{array}$ & $\begin{array}{l}729 \\
(15)\end{array}$ & $\begin{array}{l}823 \\
(10)\end{array}$ \\
\hline $\begin{array}{l}\text { Serum iron } \\
(\mu \mathrm{g} / 100 \mathrm{ml})\end{array}$ & $\begin{array}{l}99 \\
(9)\end{array}$ & $\begin{array}{l}109 \\
(16)\end{array}$ & $\begin{array}{c}90 \\
(16)\end{array} \pm 7$ & $\begin{array}{l}101 \\
(16)\end{array}$ & $\begin{array}{c}91 \\
(10)\end{array} \pm 10$ \\
\hline $\begin{array}{l}\text { Plasma calcium } \\
(\mathrm{mg} / 100 \mathrm{ml})\end{array}$ & $\begin{array}{l}9 \cdot 6 \pm 0 \cdot 1 \\
(12)\end{array}$ & $\begin{array}{l}9 \cdot 7 \\
(16)\end{array}$ & $\begin{array}{l}9 \cdot 6 \pm 0 \cdot 1 \\
(17)\end{array}$ & $\begin{array}{l}9 \cdot 7 \pm 0.1 \\
(16)\end{array}$ & $\begin{array}{l}9 \cdot 7 \\
(11)\end{array}$ \\
\hline $\begin{array}{l}\text { Plasma phosphorus } \\
(\mathrm{mg} / 100 \mathrm{ml})\end{array}$ & $\begin{array}{l}4 \cdot 8 \pm 0 \cdot 1 \\
(12)\end{array}$ & $\begin{array}{l}4 \cdot 6 \pm 0 \cdot 1 \\
(16)\end{array}$ & $\begin{array}{l}4 \cdot 4 \\
(16)\end{array}$ & $\begin{array}{l}4 \cdot 4 \pm 0 \cdot 1 \\
(16)\end{array}$ & $\begin{array}{l}4 \cdot 1^{2} \pm 0.2 \\
(11)\end{array}$ \\
\hline $\begin{array}{l}\text { Alkaline phosphatase } \\
\text { KA units } 100 \mathrm{ml}\end{array}$ & $\begin{array}{c}31 \\
(12)\end{array} \pm 3$ & $\begin{array}{c}31 \\
(16)\end{array} \pm 1$ & $\begin{array}{c}32 \\
(17)\end{array} \pm 1$ & $\begin{array}{c}34 \\
(16)\end{array} \pm 2$ & $32 \pm 2$ \\
\hline $\begin{array}{l}\text { Plasma proteins } \\
(\mathrm{g} / 100 \mathrm{ml})\end{array}$ & $\begin{array}{l}7 \cdot 0 \pm 0 \cdot 1 \\
(12)\end{array}$ & $\begin{array}{l}6 \cdot 8 \pm 0 \cdot 1 \\
(16)\end{array}$ & $\begin{array}{l}6 \cdot 8 \pm 0.1 \\
(17)\end{array}$ & $\begin{array}{l}6 \cdot 8 \pm 0 \cdot 1 \\
(14)\end{array}$ & $\begin{array}{l}7 \cdot 1 \\
(10)\end{array} \pm 0 \cdot 1$ \\
\hline
\end{tabular}

Table I Mean values ( \pm SEM) of various biochemical determinations during the first two years of cholestyramine therapy ${ }^{1}$

${ }^{1}$ Number of children shown in brackets

${ }^{2}$ Significantly lower than pretreatment value $(P<0.05)$ 


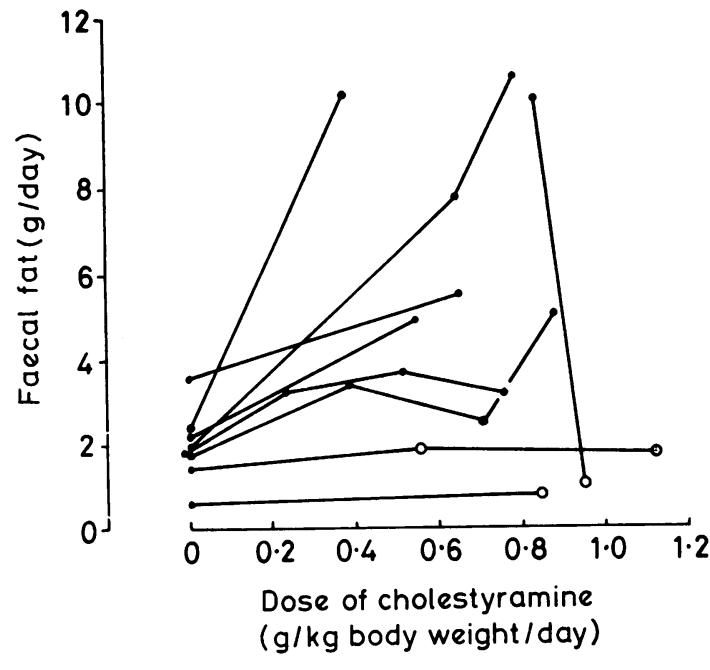

Fig 1 Faecal fat in nine children on cholestyramine. 0 Normal diet; $\bigcirc=$ low-fat diet.

a low-fat diet, developed steatorrhoea with a faecal fat of $10 \mathrm{~g} /$ day when his dietary fat intake increased to normal, although the cholestyramine dosage remained virtually unchanged.

\section{FAT-SOLUBLE VITAMINS}

Serum vitamin A concentrations in most patients remained within the normal range although a few isolated estimations were low. The mean values are given in table I. For the first 18 months of cholestyramine treatment, the mean serum vitamin A remained relatively constant, but the mean value of $83 \mathrm{IU} / \mathrm{ml}$ obtained for eight patients for the period 19-24 months after starting cholestyramine, although still well within the normal range, is significantly lower than the pretreatment value for the group $(P<0.05)$. Serum vitamin $E$ concentrations in all patients remained within normal limits; a slight downward trend appeared during the two-year period and the value at two years is significantly lower than the pretreatment value $(\mathrm{P}<0.05)$.
Prothrombin time remained normal (within two seconds of control) in all children, indicating adequate absorption of vitamin $\mathbf{K}$.

Vitamin D was not measured directly. Plasma calcium and alkaline phosphatase remained normal in all patients and mean values remained almost constant over the whole period of follow up. There was a significant fall in mean serum inorganic phosphorus during the period of follow up $(\mathrm{P}<$ 0.01 ) and in some patients values have become below the normal range (table I).

\section{FOLIC ACID}

Serum folate was measured in nine children before treatment started and has been measured at intervals in the 17 patients receiving cholestyramine. Mean serum folate concentrations for the group are given in table II. Although there was fluctuation in the values for any individual child, for the group as a whole progressive lowering of mean serum folate occurred during the treatment period, the mean values after one year being significantly lower than the pretreatment values $(\mathrm{P}<0.01)$.

Red blood cell folate estimations also showed that most values were already below the normal range after one year of treatment and continued to fall (table II); this provides further evidence of folate deficiency. None of the children became anaemic, but when it was clear that folate deficiency was occurring on cholestyramine therapy supplementary folic acid, $5 \mathrm{mg}$ daily, was given to all patients, and subsequently serum and red blood cell folate have returned to normal.

\section{IRON, VITAMIN B 12 AND PLASMA PROTEINS} (TABLE I)

Serum vitamin $\mathbf{B}_{12}$ and plasma protein concentrations were all within the normal range, and no trend in mean values was observed over the time of study. Serum iron concentrations were occasionally low in individual patients, but in no patient has a low serum iron concentration persisted, and again no trend in mean values occurred over the study period.

\begin{tabular}{|c|c|c|c|c|c|c|}
\hline \multirow[t]{2}{*}{ Investigation } & \multicolumn{5}{|c|}{ Duration of Cholestyramine Treatment (Months) } & \multirow{2}{*}{$\begin{array}{l}\text { While Taking } \\
\text { Folic Acid } \\
(5 \mathrm{mg} / \text { day })\end{array}$} \\
\hline & 0 & $\rightarrow 6$ & $\rightarrow 12$ & $\rightarrow 18$ & $\rightarrow 24$ & \\
\hline $\begin{array}{l}\text { Serum folate } \\
(\mathrm{ng} / \mathrm{ml}) \\
\text { Red cell folate } \\
(\mathrm{ng} / \mathrm{ml})\end{array}$ & $\begin{array}{l}7 \cdot 7 \pm 1 \cdot 1 \\
(9) \\
-\end{array}$ & $\begin{array}{l}6 \cdot 1 \pm 0 \cdot 5 \\
(16) \\
231 \\
(4)\end{array}$ & $\begin{array}{l}5 \cdot 5 \pm 0 \cdot 5 \\
(17) \\
147 \pm 19 \\
(13)\end{array}$ & $\begin{array}{l}4^{4 \cdot 4^{2}} \pm 0.5 \\
(16) \\
138 \\
(12)\end{array}$ & $\begin{array}{l}{ }_{(9)}^{4 \cdot 4^{8}} \pm 0.4 \\
110 \quad \pm 12 \\
(9)\end{array}$ & $\begin{array}{l}31 \cdot 7 \pm 0 \cdot 3 \\
(7) \\
629 \pm 22 \\
(7)\end{array}$ \\
\hline
\end{tabular}

Table II Mean values ( $\pm S E M)$ of serum and red cell folate on cholestyramine treatment ${ }^{1}$

${ }^{1}$ Number of children shown in brackets

2Significantly lower than pretreatment value $(P<0.01)$

${ }^{3}$ Significantly lower than pretreatment value $(P<0.03)$ 


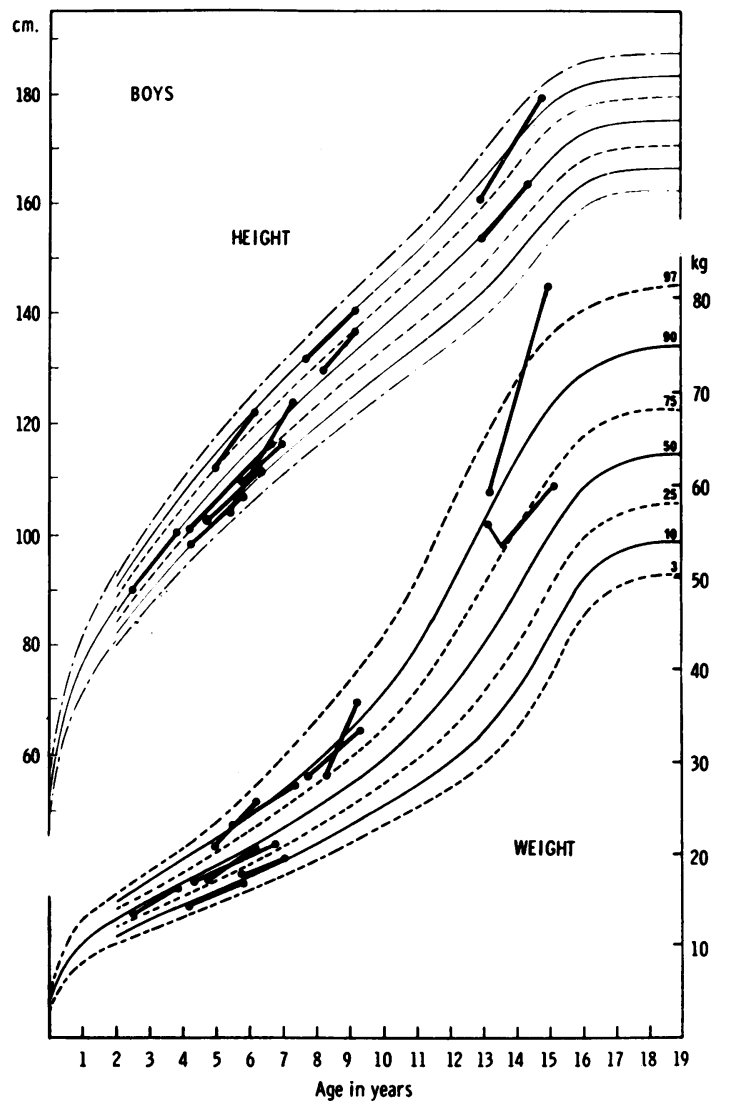

Fig 2 Growth in children on cholestyramine.

\section{GROWTH}

Figure 2 illustrates height and weight progress. In no child has growth been retarded significantly over the period studied (one to two and a half years).

\section{Discussion}

The dosage of cholestyramine used for most of these children was large compared with adult standards, a mean daily dose of $0.6 \mathrm{~g} / \mathrm{kg}$ body weight, representing an average adult equivalent dose of 30 to 40 $\mathrm{g} /$ day. In adults Hashim et al (1961) reported that cholestyramine in a dose of $30 \mathrm{~g} /$ day consistently caused steatorrhoea, and it might therefore be anticipated that steatorrhoea would occur in most children. Definite steatorrhoea (greater than 5 $\mathrm{g}$ /day) occurred in five of seven children eating normal diets, but none had diarrhoea or weight loss. There was no consistent relationship between dosage and faecal fat (fig 1).

Impaired fat absorption has been presumed to be

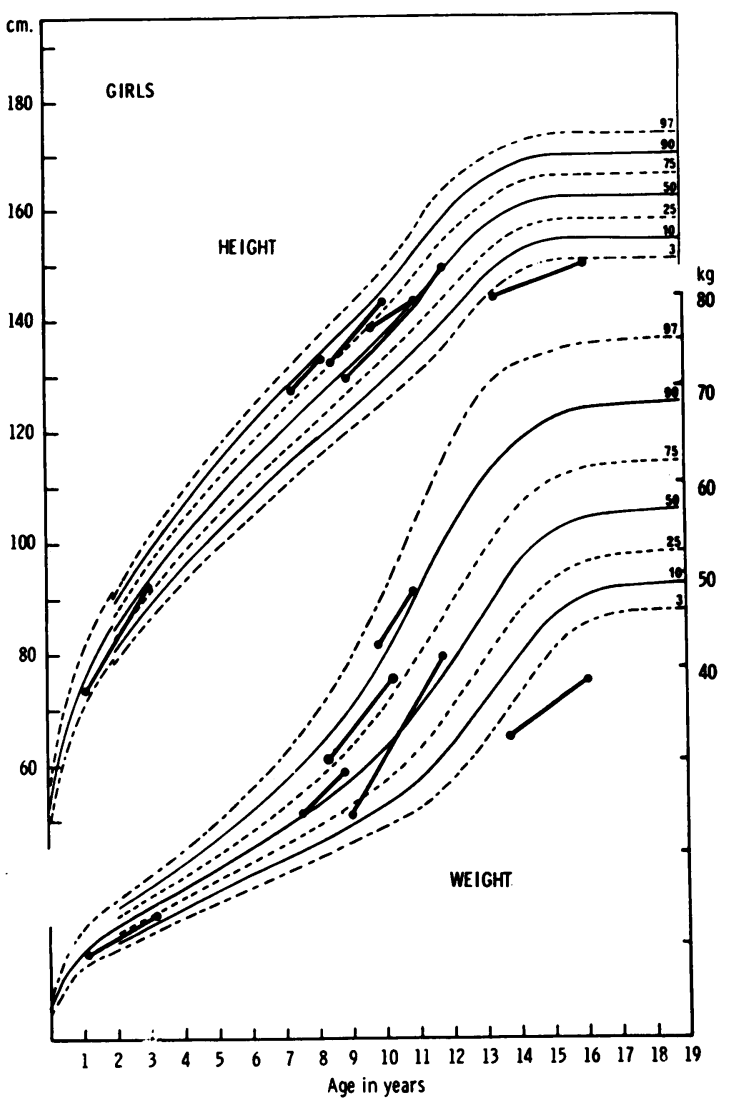

due to deficiency of available bile acids for micelle formation. Du Bois, Halt, Kuron, Hashim, and Van Itallie (1964), using Tween 80, a synthetic detergent, abolished cholestyramine-induced steatorrhoea and postulated that Tween permitted micellar solubilization. However, faecal bile acid loss in their patients also decreased when they were given Tween. Experiments in vitro (Johns and Bates, 1970) have shown considerable binding of fatty acid to cholestyramine and steatorrhoea could 6 therefore be due to direct binding of fatty acid to the resin.

Evidence for malabsorption of fat-soluble vitamins has not been well documented in adults on cholestyramine treatment. Impaired absorption of vitamin $\mathrm{K}$ due to cholestyramine has been shown in $\stackrel{\mathbb{2}}{\mathrm{C}}$ dogs (Robinson, Kelley, and Lehman, 1964) and in chicks (Whiteside, Harkins, Fluckiger, and Sareth, 8 1965) but only under extreme experimental conditions. Hypoprothrombinaemia associated with therapeutic use of cholestyramine has been reported 
in only a few patients and other potential causes of malabsorption have usually been present. Bleeding from the bowel associated with cholestyramine therapy was described in a woman who had had an ileal resection and abdominal irradiation (Gross and Brotman, 1970), and vitamin K deficiency was found in a patient with biliary cirrhosis who was receiving cholestyramine (Visintine, Michaels, Fukayama, Conklin, and Kinsell, 1961).

Cholestyramine has been shown to interfere with absorption of vitamin A under experimental conditions. Longeneker and Basu (1965) gave a standard dose of vitamin $\mathrm{A}$ with and without cholestyramine in a meal to four healthy men, and measured changes in serum vitamin A for nine hours postprandially. The simultaneous ingestion of $8 \mathrm{~g}$ of cholestyramine caused a significantly lower rise in serum vitamin A; however, smaller doses of cholestyramine were without effect. Using groups of young rats, Whiteside et al (1965) showed that the addition of 1 to $2 \%$ of cholestyramine to the diet resulted in reduced liver stores of vitamin $A$, although there were no differences in serum vitamin A levels between cholestyramine-fed and control animals. The maintenance of serum vitamin A levels in our patients for the first 18 months of treatment could be explained by relatively large liver stores of vitamin $\mathrm{A}$ which take time to become depleted. Further observations will be required to see if serum vitamin A becomes progressively lower with more prolonged treatment.

No previous studies of vitamin $E$ absorption during cholestyramine therapy have been reported. Our finding of progressive lowering of serum vitamin $E$ suggests that absorption of this vitamin may be impaired by cholestyramine.

The significant fall in plasma inorganic phosphorus concentration was unexpected, and was greater than could be attributed to the decrease which normally occurs during childhood (Arnaud, Goldsmith, Stickler, McCall, and Arnaud, 1973). This could be due to binding of dietary phosphate to the resin in the gut. Alternatively, there might be malabsorption of calcium or vitamin $D$, with increased parathyroid activity resulting in increased urinary phosphate loss, but with normal plasma calcium concentrations.

In rats given cholestyramine Thompson and Thompson (1969) showed impaired absorption of vitamin $\mathrm{D}$, but normal calcium absorption, whereas Harkins and Hagerman (1965) had shown increased faecal calcium loss associated with steatorrhoea. Osteomalacia attributed to cholestyramine has been described in only one patient, a woman who had had an ileal resection (Heaton, Lever, and Barnard, 1972).

Further studies will be required to elucidate the reasons for the lowering of plasma inorganic phosphorus concentration on cholestyramine therapy.

Dietary folate occurs mainly as polyglutamates which are anionic and therefore liable to bind to cholestyramine resin; folate malabsorption is thus to be expected, and it is perhaps surprising that it has not been previously reported. A supplement of folic acid of $5 \mathrm{mg}$ daily appears adequate to prevent folate depletion and we consider that it should be given routinely to all patients on long-term anionexchange resins.

Although the period of follow up in our patients is still relatively short, there would not appear to be any indication to control the steathorrhoea with a low-fat diet. It is probably prudent to continue estimation of serum vitamins $A$ and $E$ and prothrombin time at intervals; at present the routine administration of additional fat-soluble vitamins appears unnecessary.

In our study there is no evidence that cholestyramine impairs absorption of iron or vitamin $B_{12}$. The normal growth rate in children and the maintenance of plasma protein concentration provide further evidence of the safety of prolonged administration of cholestyramine.

We would like to thank the staff of the routine laboratories of The Hospital for Sick Children for their help in the investigation of the children in this study.

\section{References}

Arnaud, S. B., Goldsmith, R. S., Stickler, G. B., McCall, J. T., and Arnaud, C. D. (1973). Serum parathyroid hormone and blood minerals: interrelationships in normal children. Pediat. Res., 7, 485-493.

Bergen, S. S., Jr., Van Itallie, T. B., Tennent, D. M., and Sebrell, W. H. (1959). Effect of an anion exchange resin on serum cholesterol in man. Proc. Soc. exp. Biol. (N. Y.), 102, 676-679.

Datta, D. V., and Sherlock, S. (1963). Treatment of pruritis of obstructive jaundice with cholestyramine. Brit. med. J., 1, 216219.

Du Bois, J. J., Holt, P. R., Kuron, G. W., Hashim, S. A., and Van Itallie, T. B. (1964). Effect of Tween 80 on cholestyramineinduced malabsorption. Proc. Soc. exp. Biol. (N.Y.), 117, 226229.

Fallon, H. J., and Woods, J. W. (1968). Response of hyperlipoproteinemia to cholestyramine resin. J. Amer. med. Ass., 204, 1161-1164.

Gross, L., and Brotman, M. (1970). Hypoprothrombinemia and hemorrhage associated with cholestyramine therapy. Ann. intern. Med., 72, 95-96.

Harkins, R. W., and Hagerman, L. M. (1965). Retention of dietary fats in experimental steatorrhea induced by cholestyramine. (Abstr.) Fed. Proc., 24, 375.

Hashim, S. A., Bergen, S. S., Jr., and Van Itallie, T. B. (1961). Experimental steatorrhea induced in man by bile acid sequestrant. Proc. Soc. exp. Biol. (N.Y.), 106, 173-175.

Hashim, S. A., and Van Itallie, T. B. (1965). Cholestyramine resin therapy for hypercholesterolemia. J. Amer. med. Ass., 192. 289-293.

Heaton, K. W., Lever, J. V., and Barnard, D. (1972). Osteomalacia associated with cholestyramine therapy for postileectomy diarrhea. Gastroenterology, 62, 642-646. 
Hofmann, A. F., and Poley, J. R. (1969). Cholestyramine treatment of diarrhea associated with ileal resection. New Engl. J. Med., 281, 397-402.

Johns, W. H., and Bates, T. R. (1970). Quantification of the binding tendencies of cholestyramine II. Mechanisms of interaction with bile salt and fatty acid salt anions. J. pharm. Sci., 59, 329-333.

van de Kamer, J. H., ten Bokkel Huinink, H., and Weyers, H. A. (1949). Rapid method for the determination of fat in faeces. J. biol. Chem., 177, 347-355.

Longenecker, J. B., and Basu, S. G. (1965). Effect of cholestyramine on absorption of amino acids and vitamin $A$ in man. Fed. Proc., 24, 375.

Quaife, M. L., and Harris, P. L. (1944). The chemical estimation of tocopherols in blood plasma. J. biol. Chem., 156, 499-505.

Robinson, H. J., Kelley, K. L., and Lehman, E. G. (1964). Effect of cholestyramine, a bile acid binding polymer, on vitamin $\mathrm{K}$ absorption in dogs. Proc. Soc. exp. Biol. (N.Y.), 115, 112-115. Smith, L. H., Fromm, H., and Hofmann, A. F. (1972). Acquired hyperoxaluria, nephrolithiasis, and intestinal disease. New Engl. J. Med., 286, 1371-1375.

Thompson, W. G., and Thompson, G. R. (1969). Effect of cholestyrumine on the absorption of vitamin $\mathrm{D}_{\mathrm{a}}$ and calcium. Gut, 10, 717-722.

Visintine, R. E., Michaels, G. D., Fukayama, G., Conklin, J., and Kinsell, L. W. (1961). Xanthomatous biliary cirrhosis treated with cholestyramine. Lancet, 2, 341-343.

Whiteside, C. H., Harkins, R. W., Fluckiger, H. B., and Sarett, H. P. (1965). Utilization of fat-soluble vitamins by rats and chicks fed cholestyramine, a bile acid sequestrant. Amer. J. clin. Nutr., 16, 309-314. 